\title{
Wpływ niobu na właściwości warstw wierzchnich napawanych samoosłonowymi drutami proszkowymi o stopiwie Fe-Cr-C
}

\section{Effect of niobium on properties of hardfaced layers surface welded by Fe-Cr-C open arc flux-cored wire electrodes}

\section{Streszczenie}

Badano wpływ zawartości niobu w samoosłonowych drutach proszkowych ze stopiwem Fe-Cr-C na twardość, strukturę oraz odporność na zużycie ścierne typu metal-minerał napoin jedno- i dwuwarstwowych. Stwierdzono niejednoznaczny wpływ zmiany zawartości niobu w zakresie od 4 do $10 \%$ na te właściwości w zależności od liczby warstw napawanych. Zauważono, że wyżarzanie odprężające $\mathrm{w}$ temperaturze $650^{\circ} \mathrm{C}$ powoduje zmniejszenie twardości, jak również zwiększenie zużycia ściernego wszystkich badanych napoin.

\section{Wstęp}

Druty proszkowe o stopiwie typu $\mathrm{Fe}-\mathrm{Cr}-\mathrm{C}$ są spoiwami powszechnie stosowanymi do napawania prewencyjnego lub regeneracyjnego powierzchni roboczych maszyn i urządzeń pracujących w warunkach zużycia typu metal-minerał, jak również do wytwarzania płyt bimetalowych (pancernych), które znajdują szerokie zastosowanie w przemyśle wydobywczym i cementowym, górnictwie, hutnictwie, budownictwie itd. Stopiwo tych drutów zawiera zazwyczaj $3,5 \div 5,5 \%$ C oraz $15 \div 35 \% \mathrm{Cr}$, a wysoka odporność na zużycie ścierne wynika z obecności twardych węglików chromu, głównie $\mathrm{M}_{7} \mathrm{C}_{3}$, w strukturze materiału warstw napawanych. Niektóre stopiwa $\mathrm{Fe}-\mathrm{Cr}-\mathrm{C}$ zawierają ponadto dodatek niobu, który przede wszystkim zwiększa odporność warstw napawanych na ścieranie w podwyższonej

Dr inż. Jerzy Niagaj - Instytut Spawalnictwa, Gliwice.
Abstract

The influence of niobium in $\mathrm{Fe}-\mathrm{Cr}-\mathrm{C}$ open arc fluxcored wires electrodes on hardness, microstructure and abrasion resistance of overlay welds consisted of one and two layers are investigated. It was found that variation of niobium content in range from 4 to $10 \%$ has ambiguous effect on these properties depending on number of layers. It was found also that heat treatment at $650^{\circ} \mathrm{C}$ cause fall dawn hardness and abrasion resistance of all investigated overlay welds. temperaturze, ale też przyczynia się do poprawy tej właściwości również w temperaturze otoczenia.

W artykule przedstawiono wyniki badań wpływu zawartości niobu w stopiwie samoosłonowych drutów proszkowych na strukture, twardość oraz odporność na ścieranie napawanych warstw wierzchnich metalminerał.

\section{Materiały i metody badań}

W celu określenia wpływu niobu na twardość, strukturę oraz odporność na ścieranie warstw napawanych $\mathrm{Fe}-\mathrm{Cr}-\mathrm{C}-\mathrm{Nb}$ wykonano doświadczalne warianty samoosłonowych drutów proszkowych o średnicy 2,0 mm. Stopiwo drutów zawierało $4 \div 10 \%$ niobu przy zachowaniu podobnych zawartości węgla i chromu, odpowiednio ok. $4,5 \div 20 \%$. Do badań porównawczych, jako wzorcowy, zastosowano jeden $z$ dostępnych na rynku samoosłonowych drutów proszkowych o średnicy 2,0 mm, który oznaczono literą C (tabl. I). 
Tablica I. Skład chemiczny stopiwa samoosłonowego drutu C

Table I. Chemical composition of open arc flux-cored $\mathrm{C}$ wires

\begin{tabular}{|c|c|c|c|c|c|}
\hline \multirow{2}{*}{ Symbol drutu } & \multirow{2}{*}{ Źródło danych } & \multicolumn{3}{|c|}{ Pierwiastki chemiczne w stopiwie, \% wag. } \\
\cline { 3 - 6 } & & $\mathrm{C}$ & $\mathrm{Cr}$ & $\mathrm{Nb}$ \\
\hline- & katalog & 5,4 & 22 & 7 \\
\hline C & badania własne & 4,04 & 20,85 & 7,16 \\
\hline
\end{tabular}

Jedno- i dwuwarstwowe napoiny próbne wykonywano na powierzchni blachy ze stali S235 o wymiarach 350x70x24 mm. Pierwszą warstwę o szerokości ok. $60 \mathrm{~mm}$ napawano na całej długości blachy, układając obok siebie $6 \div 7$ ściegów. Następnie na odcinku 1/2 długości blachy wykonywano drugą warstwę. Po zakończeniu napawania z obydwu części próbnej blachy wycinano próbki o wymiarach ok. $65 \times 60 \mathrm{~mm}$ do badań odporności na ścieranie, twardości oraz struktury.

Pomiary twardości warstw wierzchnich wykonywano na próbkach do badań odporności na zużycie ścierne z zastosowaniem twardościomierza cyfrowego BRICKERS 220 metodą Vickersa przy obciążeniu 294,3 N (30 kG), na szlifowanej powierzchni próbek. Dla każdego wariantu drutu proszkowego wykonywano co najmniej pięć pomiarów twardości.

Badania odporności warstw wierzchnich typu metalminerał na zużycie ścierne prowadzono na stanowisku laboratoryjnym przedstawionym na rysunku 1 , zgodnie z wymaganiami normy ASTM G65 Procedure A [1]. Próbki do badań $z$ napoinami jedno- $\mathrm{i}$ dwuwarstwowymi mocowano w uchwycie urządzenia badawczego i dociskano do przeciwpróbki (tarczy gumowej) siłą ok. 130 $\mathrm{N}$. Jako ścierniwa używano piasku kwarcowego o ziarnistości maks. 0,4 mm. Droga tarcia wynosiła $4309 \mathrm{~m}$. W każdym wariancie drutu oraz każdego rodzaju napoin (jedno- lub dwuwarstwowej) wykonywano co najmniej trzy próby. Przed rozpoczęciem prób ścierania oraz po ich zakończeniu próbki ważono $z$ dokładnością $0,002 \mathrm{~g}$ na wadze AD600 firmy AXIS.

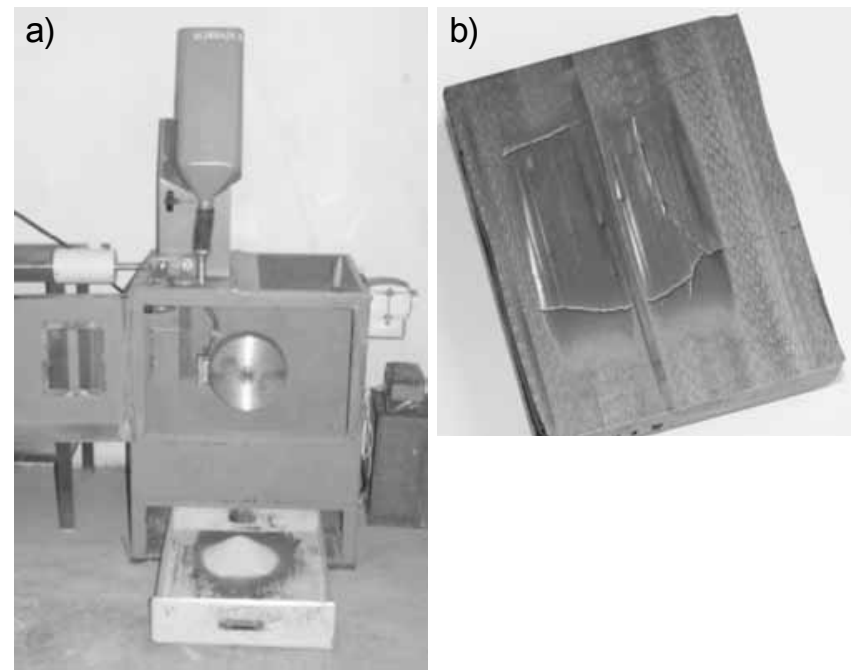

Rys. 1. Stanowisko laboratoryjne do badań odporności na zużycie ścierne wg ASTM G65 (a) oraz charakter zużycia powierzchni próbki po badaniach (b)

Fig. 1. The laboratory stadion for resistance to wear ASTM G65 testing (a) and nature of the wear surface of the sample after testing (b)

\section{Wyniki badań}

\section{Badanie twardości napoin}

Badania twardości warstw napawanych wykonano po napawaniu i obróbce cieplnej, polegającej na wyżarzaniu odprężającym $w$ temperaturze $650^{\circ} \mathrm{C}$ przez $1 \mathrm{~h}$. Włączenie do badań próbek poddanych obróbce cieplnej było uwarunkowane tym, że druty proszkowe zawierające $w$ składzie stopiwa niob, są zalecane do pracy w podwyższonej temperaturze w zakresie $300 \div 550^{\circ} \mathrm{C}$ (w zależności od wytycznych poszczególnych producentów materiałów spawalniczych). Temperaturę obróbki cieplnej w wysokości $650^{\circ} \mathrm{C}$ wybrano na podstawie danych zawartych w katalogach niektórych producentów drutów proszkowych, wskazujących na zmniejszenie twardości warstw napawanych o zawartości ok. $7 \%$ niobu, przy odpuszczeniu ich w temperaturze powyżej $500 \div 550{ }^{\circ} \mathrm{C}$, jak również w celu porównania uzyskanych wyników z wynikami badań, gdzie zastosowano podobne parametry obróbki cieplnej [2].

Analiza danych przedstawionych w tablicy II wykazuje, że w stanie po napawaniu twardość napoin jednowarstwowych jest nieco mniejsza niż twardość napoin dwuwarstwowych oraz charakteryzuje się większym rozrzutem wartości poszczególnych pomiarów, co wiąże się z nierównomiernością wymieszania spoiwa $z$ materiałem podłoża. Jest to cecha charakterystyczna, właściwa dla wszystkich napoin jednowarstwowych. Wyniki pomiarów wykazują również brak istotnych różnic pomiędzy twardością napoin dwuwarstwowych (wartości średnie mieszczą się w zakresie 60,3 $\div 63,6$ HRC) w zależności od zawartości niobu, która zmienia się w zakresie $4 \div 10 \%$ (tabl. II). Zauważono, że twardość napoin wykonanych drutami proszkowymi zawierającymi dodatek $0,2 \div 0,3 \%$ boru (druty o symbolach $923 B \div 925 B$ oraz C) jest nieco większa, niż twardość napoin uzyskanych przy zastosowaniu drutów niezawierających tego pierwiastka $(926 \div 928)$. Obserwowany wzrost jest tak niewielki, że na podstawie uzyskanych wyników można stwierdzić tylko tendencję wzrostową, a nie rzeczywiste zwiększenie twardości.

W tablicy II przedstawiono również wyniki pomiarów twardości napoin czterowarstwowych, które wykonano w celu wyeliminowania wymieszania spoiwa $z$ podłożem oraz uzyskania danych charakteryzujących twardość stopiwa. Analiza uzyskanych wartości wskazuje, że twardość stopiwa (napoina czterowarstwowa) jest bardzo zbliżona do twardości napoin dwuwarstwowych, co sugeruje, że przy tego rodzaju drutach proszkowych stopień wymieszania spoiwa z podłożem jest minimalny już po ułożeniu drugiej warstwy. 
Tablica II. Twardość napawanych warstw wierzchnich

Table II. Hardness of surface layers after surface welding

\begin{tabular}{|c|c|c|c|c|c|c|c|}
\hline \multirow{2}{*}{ Symbol drutu } & \multicolumn{4}{|c|}{ Zawartość podstawowych pierwiastków w stopiwie, \% wag. } & \multicolumn{3}{|c|}{ Twardość ${ }^{*}$, HRC } \\
\hline & $\mathrm{C}$ & $\mathrm{Cr}$ & $\mathrm{Nb}$ & B & I warstwa & II warstwa & IV warstwa (stopiwo) \\
\hline $\mathrm{C}$ & 4,04 & 20,85 & 7,16 & 0,22 & $\begin{array}{c}57,0 \div 58,9 \\
57,8\end{array}$ & $\begin{array}{c}61,2 \div 63,8 \\
62,5\end{array}$ & $\begin{array}{c}60,5 \div 63,5 \\
62,0\end{array}$ \\
\hline $923 \mathrm{~B}$ & 4,63 & 23,03 & 3,94 & 0,33 & $\begin{array}{c}61,0 \div 64,7 \\
62,8 \\
\end{array}$ & $\begin{array}{c}62,5 \div 64,5 \\
63,6 \\
\end{array}$ & $\begin{array}{c}63,1 \div 64,9 \\
63,9 \\
\end{array}$ \\
\hline 924B & 4,57 & 21,06 & 6,42 & 0,35 & $\begin{array}{c}58,0 \div 62,6 \\
60,1\end{array}$ & $\begin{array}{c}60,1 \div 63,5 \\
62,3\end{array}$ & $\begin{array}{c}59,0 \div 62,8 \\
60,9\end{array}$ \\
\hline $925 B$ & 4,50 & 15,89 & 10,48 & 0,38 & $\begin{array}{c}56,5 \div 61,7 \\
59,5\end{array}$ & $\begin{array}{c}61,8 \div 66,4 \\
64,1\end{array}$ & $\begin{array}{c}62,9 \div 64,1 \\
63,4\end{array}$ \\
\hline 926 & 4,90 & 25,70 & 3,78 & - & $\begin{array}{c}57,6 \div 62,7 \\
59,7\end{array}$ & $\begin{array}{c}59,7 \div 62,3 \\
61,0\end{array}$ & $\begin{array}{c}62,1 \div 65,0 \\
63,6\end{array}$ \\
\hline 927 & 4,95 & 20,88 & 6,61 & - & $\begin{array}{c}59,5 \div 64,7 \\
61,2 \\
\end{array}$ & $\begin{array}{c}59,7 \div 64,0 \\
61,6 \\
\end{array}$ & $\begin{array}{c}62,1 \div 63,6 \\
62,0 \\
\end{array}$ \\
\hline 928 & 4,50 & 15,35 & 10,21 & - & $\begin{array}{c}55,2 \div 56,5 \\
55,7 \\
\end{array}$ & $\begin{array}{c}59,0 \div 61,0 \\
60,3\end{array}$ & $\begin{array}{c}58,3 \div 60,4 \\
59,4 \\
\end{array}$ \\
\hline
\end{tabular}

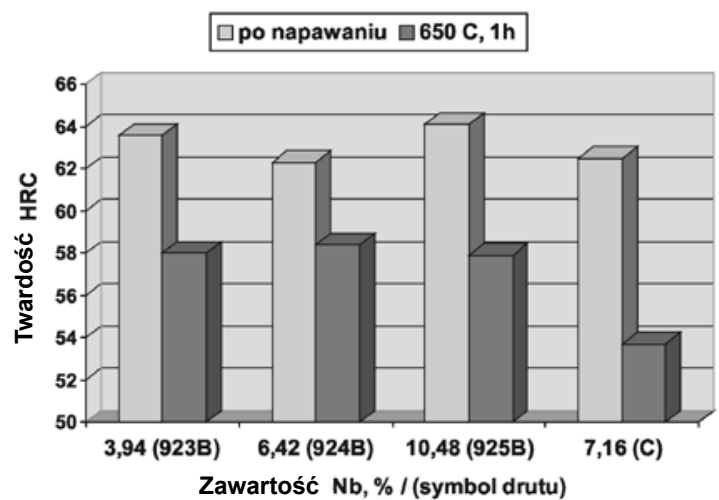

Rys. 2. Twardość napoin dwuwarstwowych $z$ dodatkiem $B$ po napawaniu i obróbce cieplnej w $650^{\circ} \mathrm{C}$ przez $1 \mathrm{~h}$

Fig. 2. Hardness of double-layer padding weld with $B$ addition after surface welding and heat treatment $650^{\circ} \mathrm{C}, 1 \mathrm{~h}$

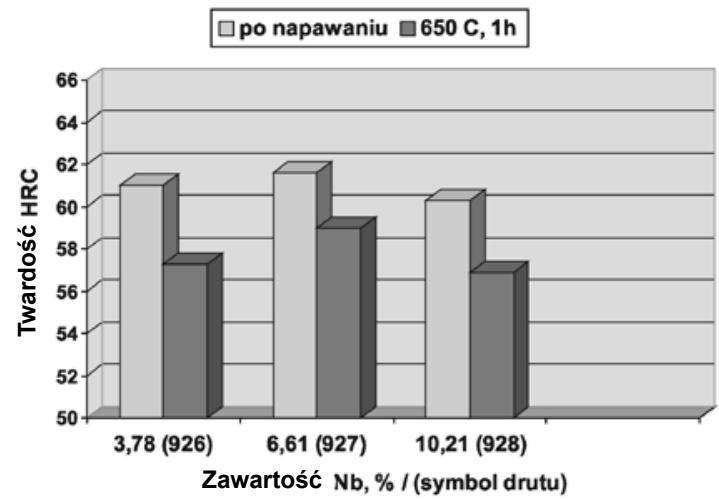

Rys. 3. Twardość napoin dwuwarstwowych bez dodatku boru po napawaniu i obróbce cieplnej w $650^{\circ} \mathrm{C}$ przez $1 \mathrm{~h}$.

Fig. 3. Hardness of double-layer padding weld without $B$ addition after surface welding and heat treatment $650^{\circ} \mathrm{C}, 1 \mathrm{~h}$

Wyniki pomiarów twardości napoin po wyżarzaniu odprężającym w temperaturze $650^{\circ} \mathrm{C}$ przez $1 \mathrm{~h}$ (rys. 2 i 3) wykazują, że niezależnie od zawartości niobu lub obecności boru w składzie stopiwa drutów proszkowych, następuje spadek twardości, którego wartość wynosi ok. 5 HRC w przypadku drutów z dodatkiem boru (rys. 2) oraz 3 HRC przy braku boru w stopiwie (rys. 3). Po obróbce cieplnej wartości średnie twardości napoin dwuwarstwowych wykonanych z zastosowaniem wszystkich doświadczalnych drutów proszkowych wynoszą $58 \pm 1 \mathrm{HRC}$. Dla porównania, w stanie po napawaniu twardość tych napoin mieści się $\mathrm{w}$ zakresie 60,3 $\div 63,6$ HRC (tabl. II).

\section{Badanie odporności na ścieranie napoin metal-minerał}

Badaniom odporności na ścieranie wg ASTM G65 poddawano próbki o wymiarach ok. $65 \times 60 \mathrm{~mm}$, na których wykonano pomiary twardości. Wyniki badań wykazują, że, odporność na zużycie ścierne jest mniejsza niż napoin dwuwarstwowych wszystkich napoin jednowarstwowych (tabl. III). Podobny charakter zmiany wartości pomiarowych zauważono również podczas pomiarów twardości (tabl. II). W obydwu przypadkach tłumaczy się to większym stopniem wymieszania spoiwa z podłożem, co powoduje zmniejszenie zawartości węgla i pierwiastków stopowych w napoinach oraz większą niejednorodność składu chemicznego warstw napawanych.

W wyniku badań odporności na ścieranie stwierdzono, że zwiększenie zawartości niobu z 4 do 10\% powoduje wzrost ubytku masy w przypadku napoin dwuwarstwowych (rys. 4, 5). Przy napawaniu jednowarstwowym, wzrost zawartości niobu początkowo powoduje zwiększenie odporności na zużycie ścierne (spadek ubytku masy), a przy dalszym zwiększeniu zawartości do 10\%, a właściwość ta ulega niewielkiej poprawie (drut $z$ borem) lub pogorszeniu (drut bez boru).

Analiza wpływu boru na zmianę zużycia ściernego badanych próbek wykazała, że dodatek ok. 0,35\% boru powoduje nieduże zmniejszenie zużycia warstw metal-minerał tylko w przypadku napoin jednowarstwowych. Zużycie ścierne napoin dwuwarstwowych kształtuje się natomiast na podobnym poziomie, niezależnie od obecności boru w składzie stopiwa samoosłonowych drutów proszkowych (tabl. III).

Badania wpływu obróbki cieplnej na wielkość zużycia warstw metal-minerał wykazały, że wyżarzanie odprężające w temperaturze $650^{\circ} \mathrm{C}$ przez $1 \mathrm{~h}$ zawsze powoduje zmniejszenie odporności na zużycie 
Tablica III. Odporność napoin metal-minerał na zużycie ścierne wg ASTM G65 Procedure A, stan po napawaniu

Table III. Abrasive-resistance of metal-mineral type of padding welds acc. to ASTM G65 Procedure A, after surface welding state

\begin{tabular}{|c|c|c|c|c|c|c|}
\hline \multirow{2}{*}{ Symbol drutu } & \multicolumn{4}{|c|}{ Zawartość podstawowych pierwiastków w stopiwie, \% wag. } & \multicolumn{2}{|c|}{ Ubytek masy*, g } \\
\hline & C & $\mathrm{Cr}$ & $\mathrm{Nb}$ & $B$ & I warstwa & II warstwa \\
\hline C & 4,04 & 20,85 & 7,16 & 0,22 & $\begin{array}{c}0,360 \div 0,470 \\
0,420\end{array}$ & $\begin{array}{c}0,310 \div 0,454 \\
0,385\end{array}$ \\
\hline $923 \mathrm{~B}$ & 4,63 & 23,03 & 3,94 & 0,33 & $\begin{array}{c}0,290 \div 0,450 \\
0,347\end{array}$ & $\begin{array}{c}0,140 \div 0,222 \\
0,173\end{array}$ \\
\hline 924B & 4,57 & 21,06 & 6,42 & 0,35 & $\begin{array}{c}0,280 \div 0,380 \\
0,343\end{array}$ & $\begin{array}{c}0,200 \div 0,270 \\
0,251\end{array}$ \\
\hline 925B & 4,50 & 15,89 & 10,48 & 0,38 & $\begin{array}{c}0,220 \div 0,340 \\
0,290\end{array}$ & $\begin{array}{c}0,210 \div 0,344 \\
0,306\end{array}$ \\
\hline 926 & 4,90 & 25,70 & 3,78 & - & $\begin{array}{c}0,380 \div 0,600 \\
0,463\end{array}$ & $\begin{array}{c}0,140 \div 0,270 \\
0,184\end{array}$ \\
\hline 927 & 4,95 & 20,88 & 6,61 & - & $\begin{array}{c}0,270 \div 0,380 \\
0,343\end{array}$ & $\begin{array}{c}0,194 \div 0,350 \\
0,242\end{array}$ \\
\hline 928 & 4,50 & 15,35 & 10,21 & - & $\begin{array}{c}0,320 \div 0,490 \\
0,433\end{array}$ & $\begin{array}{c}0,300 \div 0,350 \\
0,332\end{array}$ \\
\hline
\end{tabular}

warstw wierzchnich (rys. 6, 7). Stopień tego zmniejszenia jest bardzo podobny, niezależnie od zawartości niobu lub dodatku boru, ale zauważono, że najmniejszy wzrost ubytku masy po obróbce cieplnej wynosi ok. 0,1 g drutów zawierających $6 \div 7 \% \mathrm{Nb}$, dla zarówno z dodatkiem boru (wzrost ubytku masy 0,066 g), jak i bez jego udziału (wzrost ubytku masy 0,103 g). Maksymalny wzrost ubytku masy wynosił $0,230 \mathrm{~g}$. W związku z nieco większym wzrostem ubytku masy próbek zawierających ok. $4 \% \mathrm{Nb}$ w porównaniu z próbkami o zawartości ok. $6,5 \% \mathrm{Nb}$, odporność na ścieranie po obróbce cieplnej napoin dwuwarstwowych wykonanych tym drutami (odpowiednio o symbolach 923B i 924B oraz 926 i 927 ) uległa wyrównaniu (rys. 6, 7).

Widoczne na rysunku 6 wyniki badań odpornośc na zużycie napoin wykonanych dostępnym na rynkı drutem proszkowym o symbolu C wykazują, że ubytek masy próbki $C$ po badaniach ścieralności jest znaczni $\epsilon$ większy niż ubytek masy próbki wykonanej z zastosowaniem drutu proszkowego 924B o podobnej zawartości pierwiastków stopowych (tabl. III). Różnica w składzie chemicznym stopiw tych drutów polega tylko ne ok. 0,5\% mniejszej zawartości węgla w stopiwie drutu C, co mogłoby tłumaczyć istotnie niższą odporność na ścieranie tych napoin. Analiza wykresów przedstawionych na rysunkach 6 i 7 wykazuje jednak, że zastosowana podczas badań obróbka cieplna powoduje najwyższy wzrost ubytku masy próbek C (o ok. 0,4 g) w porównaniu ze wszystkimi napoinami wykonanymi za pomocą doświadczalnych drutów proszkowych.

\section{Badania mikrostruktury napoin}

Wyniki badań mikrostruktury napoin dwuwarstwowych wykonanych drutami proszkowymi o różnej zawartości niobu z niewielkim dodatku boru (ok. 0,35\%), w pobliżu powierzchni roboczej w stanie po napawaniu oraz obróbce cieplnej $\left(650^{\circ} \mathrm{C}, 1 \mathrm{~h}\right)$ przedstawiono na rysunku 8.

Analiza mikrostruktury napoin dwuwarstwowych wykazuje, że zarówno w stanie po napawaniu, jak i wyżarzaniu odprężających w temperaturze $650^{\circ} \mathrm{C}$ przez $1 \mathrm{~h}$, przy zawartości ok. $4 \%$ niobu w stopiwie drutu 923B oraz ok. $6,5 \%$ w stopiwie drutu 924B, w materiale drugiej warstwy napoin $w$ pobliżu lica (powierzchni roboczej) tworzą się węgliki $M_{7} C_{3}$, które są równomiernie rozmieszczone $w$ materiale napawanym. Widoczne na zdjęciach mikrostruktur różnice polegają tylko na tym, że zdecydowana większość węglików w przypadku drutu 923B ma kształt heksagonalny, natomiast w przypadku drutu 924B węgliki mają przeważnie kształt igieł (rys. 8). Kształt heksagonalny powstaje najprawdopodobniej w wyniku przecięcia węglików

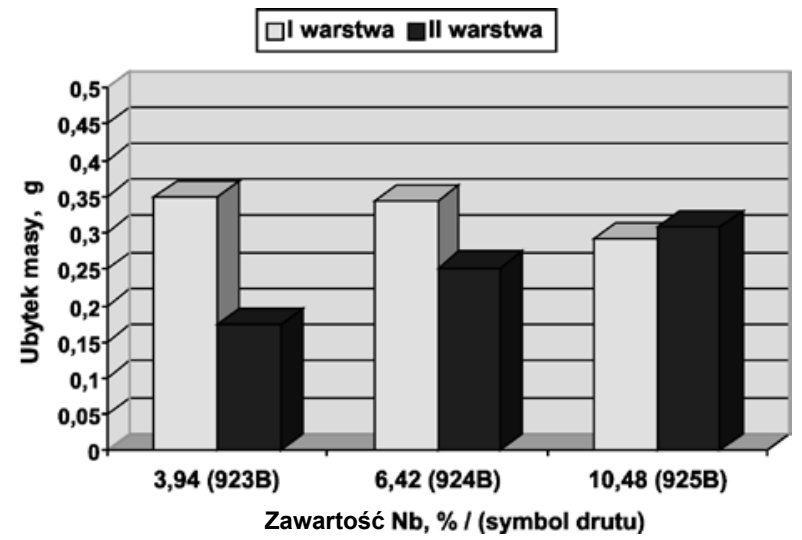

Rys. 4. Ubytek masy stwierdzony podczas badań wg ASTM G65 napoin jedno- i dwuwarstwowych $z$ dodatkiem boru po napawaniu

Fig. 4. Weight loss as the result of tests acc to ASTM G65 of single and double-layer padding welds with B addition, after surface weIding state

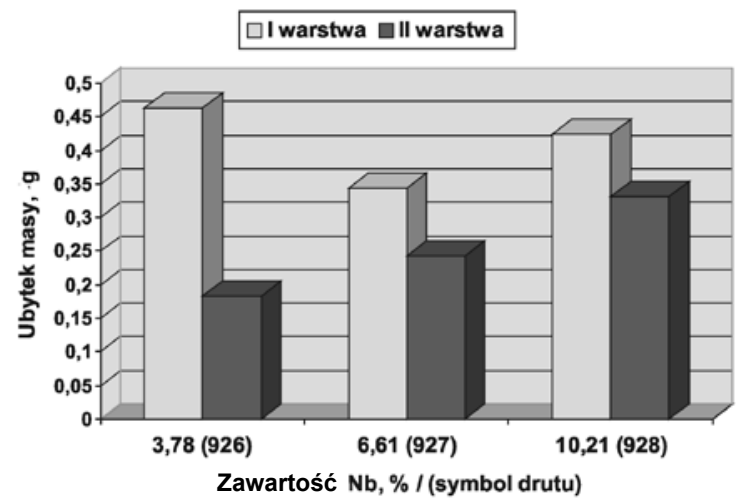

Rys. 5. Ubytek masy stwierdzony podczas wg ASTM G65 napoin jedno- i dwuwarstwowych bez dodatku boru, stan po napawaniu

Fig. 5. Weight loss as the result of tests acc to ASTM G65 of single and double-layer padding welds without B addition, after surface weIding state 




Rys. 6. Ubytek masy stwierdzony podczas badań wg ASTM G65 napoin dwuwarstwowych $z$ dodatkiem boru, stan po napawaniu i po obróbce cieplnej

Fig. 6. Weight loss as the result of tests acc to ASTM G65 of double-layer padding welds with B addition, after surface welding and heat treatment state

w postaci igieł usytuowanych wzdłuż osi wzdłużnej napoiny. Obydwie struktury sa korzystne pod względem



Przy zawartości ok. 10,5\% niobu w stopiwie drutu 925B, w materiale napoin w pobliżu lica obserwuje się najprawdopodobniej węgliki $\mathrm{NbC}$ na tle mieszaniny eutektycznej (rys. 8). Podobny kształt węglików NbC obserwowano również w białym żeliwie o składzie $3,42 \% \mathrm{C}$, $21,6 \% \mathrm{Cr}$ oraz $5,4 \% \mathrm{Nb}$ [5]. Dokładne określenie składu fazowego jest jednak możliwe z zastosowaniem metod mikroskopii elektronowej. Zanikanie wyraźnie

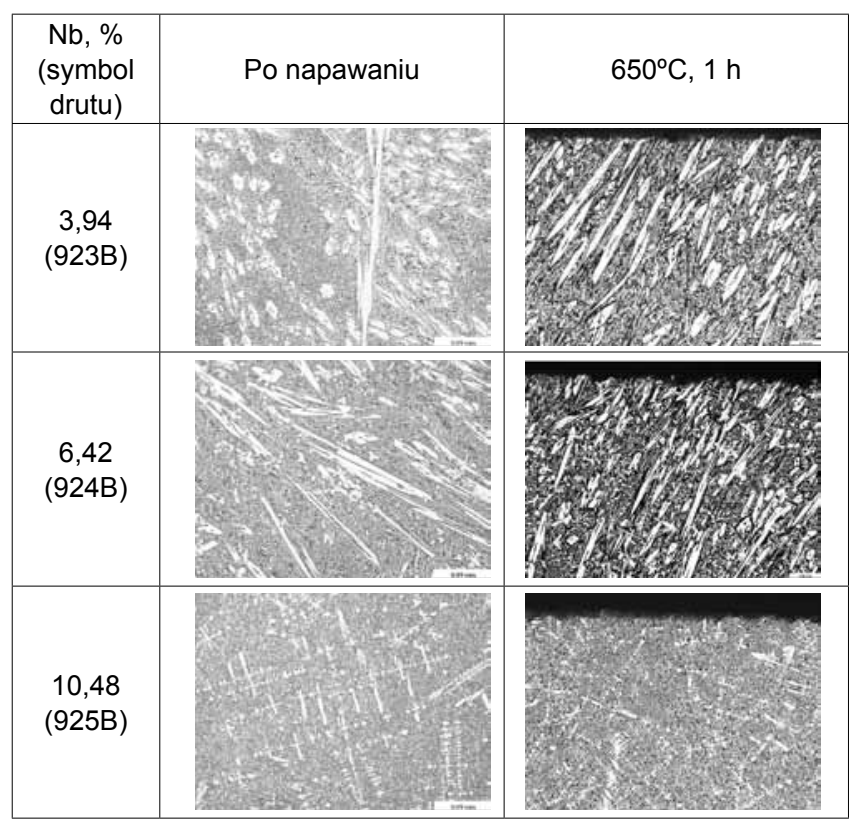

Rys. 8. Mikrostruktura napoin dwuwarstwowych w pobliżu lica (powierzchni roboczej), stan po napawaniu i obróbce cieplnej (traw. $\mathrm{FeCl} 3$ ).

Fig. 8. Microstructure of double-layer pudding Wells close to face of the weld (working area), after surface welding and heat treatment state (etching: $\mathrm{FeCl} 3$ )

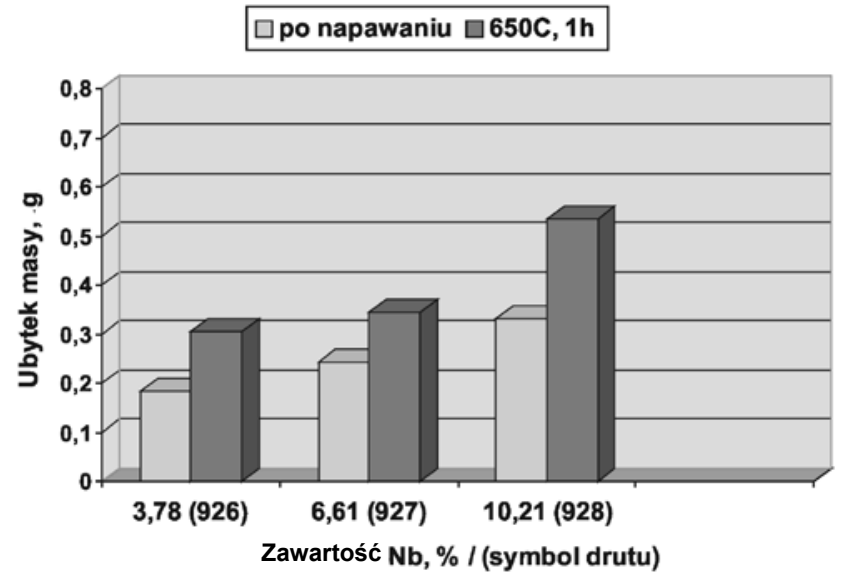

Rys. 7. Ubytek masy stwierdzony podczas badań wg ASTM G65 napoin dwuwarstwowych bez dodatku boru, stan po napawaniu i po obróbce cieplnej

Fig. 7. Weight loss as the result of tests acc to ASTM G65 of double-layer padding welds without B addition, after surface welding and heat treatment state

widocznych węglików $\mathrm{M}_{7} \mathrm{C}_{3}$ tłumaczyłoby pogorszenie odporności na zużycie ścierne warstw typu metal-minerał wykonanych drutem 925B w porównaniu z napoinami wykonanymi drutami 923B i 924B o zawartości niobu odpowiednio 3,94 i 6,42\%.

Analiza zdjęć mikrostruktury wykonanych z zastosowaniem mikroskopii optycznej nie ujawnia znaczących różnic pomiędzy mikrostruktura napoin po napawaniu i obróbce cieplnej (rys. 8). Prawdopodobnie przyczyną jest zmiękczenie osnowy, jednak w celu dokładnego określenia przyczyn zwiększenia zużycia ściernego napoin po obróbce cieplnej konieczne jest użycie bardziej precyzyjnych narzędzi badawczych.

\section{Podsumowanie}

Przeprowadzone badania wpływu zawartości niobu w składzie samoosłonowych drutów proszkowych ze stopiwem Fe-Cr-C wykazały, że zwiększenie zawar-

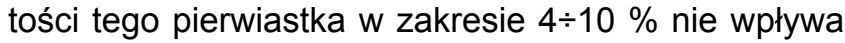
istotnie na twardość napoin dwuwarstwowych, której

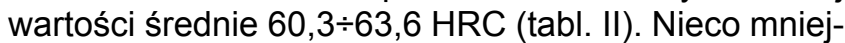
szą twardość oraz duży rozrzut wartości poszczególnych pomiarów stwierdzono w przypadku napoin jednowarstwowych $(55,7 \div 62,8 \mathrm{HRC})$. Było to do przewidzenia i tłumaczy się większym stopniem wymieszania spoiwa z podłożem, co powoduje zmniejszenie zawartości węgla i pierwiastków stopowych oraz większą niejednorodność składu chemicznego napoin jednowarstwowych.

Wyniki badań odporności na zużycie ścierne warstw typu metal-minerał przeprowadzone wg ASTM G65 wykazały niejednoznaczny wpływ zwiększenia zawartości niobu na tę właściwość. Różnice w oddziaływaniu niobu stwierdzono w zależności od liczby warstw napawanych. W przypadku napoin dwuwarstwowych 
zwiększenie zawartości niobu z 4 do $10 \%$ powodowało wzrost ubytku masy, co świadczy o zmniejszeniu odporności na zużycie ścierne (rys. 4, 5). Z kolei przy napawaniu jednowarstwowym, wzrost zawartości niobu początkowo powodował zwiększenie odporności na zużycie ścierne (spadek ubytku masy), a przy dalszym zwiększaniu zawartości $\mathrm{Nb}$ do $10 \%$, właściwość ta ulegała niewielkiej poprawie (drut z borem) lub pogorszeniu (drut bez boru). W przypadku napoin jednowarstwowych najkorzystniejsza okazała się zawartość ok. $6,5 \% \mathrm{Nb}$ w stopiwie drutów proszkowych. Badania odporności na zużycie ścierne tych napoin wykazały również, że dodatek boru w ilości ok. 0,35\% nie wpływa istotnie na tę właściwość. Stosunkowo niewielki, korzystny wpływ tego pierwiastka zauważono tylko w przypadku napoin jednowarstwowych (tabl. II).

Badania nie wykazały zależności pomiędzy twardością warstw napawanych a odpornością na zużycie ścierne, co jest zbieżne z wynikami badań przedstawionych w pracach $[6,7]$.

\section{Wnioski}

Badania odporności na ścieranie warstw metalminerał napoin dwuwarstwowych $\mathrm{Fe}-\mathrm{Cr}-\mathrm{C}$ po napawaniu oraz obróbce cieplnej wykazały, że zwiększenie zawartości niobu z 4 do $10 \%$ powoduje wzrost ubytku masy, co świadczy o zmniejszeniu odporności na zużycie ścierne. Z kolei przy napawaniu jednowarstwowym najwyższą odporność na zużycie ścierne stwierdzono przy zawartości w stopiwie ok. $6,5 \% \mathrm{Nb}$.

Wyżarzanie odprężające w temperaturze $650^{\circ} \mathrm{C}$ w ciągu $1 \mathrm{~h}$ powoduje zmniejszenie twardości napoin oraz wzrost ubytku masy podczas badań odporności na ścieranie w porównaniu ze stanem po napawaniu. Najmniejszy spadek ubytku masy po obróbce cieplnej stwierdzono w przypadku napoin wykonanych drutami proszkowymi o zawartości w stopiwie ok. 6,5\% Nb.

Stwierdzono brak zależności pomiędzy twardością warstw napawanych a odpornością na zużycie ścierne warstw typu metal-minerał.
Badania twardości oraz odporności na zużycie typu metal-minerał napoin poddanych wyżarzaniu odprężającemu w temperaturze $650^{\circ} \mathrm{C}$ przez $1 \mathrm{~h}$ wykazały, że obydwie właściwości te ulegają nieznacznemu pogorszeniu (tabl. II, rys. 6, 7). Podobny efekt opisano również w pracy [2]. Wykonane badania własne wykazały, że podczas prób określenia odporności na ścieranie, najmniejszym wzrostem ubytku masy napoin po obróbce cieplnej w porównaniu z napoinami w stanie po napawaniu charakteryzowały się stopiwa o zawartości ok. 6,5\% Nb.

Badania mikrostruktury napoin dwuwarstwowych wykazały, że zarówno po napawaniu, jak i obróbce cieplnej przy zawartości w stopiwie ok. 4\% i 6,5\% niobu w pobliżu lica napoin tworzą się równomiernie usytuowane węgliki $\mathrm{M}_{7} \mathrm{C}_{3}$. Przy zawartości ok. 10,5\% Nb w napoinach obserwuje się najprawdopodobniej węgliki $\mathrm{NbC}$ na tle mieszaniny eutektycznej. Zanikanie wyraźnie widocznych węglików $\mathrm{M}_{7} \mathrm{C}_{3}$ powodowało pogorszenie odporności na zużycie ścierne napoin wykonanych drutami o niższej zawartości niobu (3,94 i 6,42\%).

\section{Literatura}

[1] ASTM G65 Standard Test Method for Measuring Abrasion Using the Dry Sand/Rubber Wheel Apparatus.

[2] Gallo C., Hubert M.: A - Résistance à l'usure par abrasion rechargements en fontes au chrome. B - Présentation de cas concrets. Soudage et techniques connexes, 1980, nr 11/12, s. 371-386.

[3] Kotecki D.J., Ogborn J.S.: Abrasion Resistance of IronBased Hardfacing Alloys. Welding Journal, 1995, 74 (8), s. 269s-278s.

[4] Kirchgassner M., Badisch E., Franek F.: Behaviour of ironbased hardfacing alloys under abrasion and impact. Wear, 265 (2008), s. 772-779.

[5] Gregolin J.A.R., Alcantara N.G.: Solidification and Phase Equilibria in the Fe-C-Cr-NbC System. Metalluggical Transaction A, v. 22A (10), 1991, s. 2181-2186.

[6] Klimpel A., Kik T.: Erosion and abrasion wear resistance of GMA wire surfaced nanostructural deposits. Archives of Materials Science and Engineering, 2008, 30 (4), s. 121-124.

[7] Lapointe F., Dallaire S.: Erosoin and Abrasion Resistance of Boride and Carbide-Based Weld Overlays. Thermal Spray 2003, ASM International Materials Park, Ohio, USA, 2003, s. 421-426.

\section{W następnym numerze}

W następnym numerze opublikowane zostaną artykuły prezentowane na 53. Krajowej Naukowo-Technicznej Konferencji Spawalniczej „Nowe kierunki w procesach spajania i cięcia metali" w Poznaniu. 